\title{
Anemia of Chronic Disease in Chronic Obstructive Pulmonary Disease: A Case-Control Study of Cardiopulmonary Exercise Responses
}

\author{
Afroditi K. Boutou $^{\mathrm{a}}$ Ioannis Stanopoulos ${ }^{\mathrm{a}}$ Georgia G. Pitsiou ${ }^{\mathrm{a}}$ \\ Theodoros Kontakiotis $^{b}$ George Kyriazis ${ }^{c}$ Lazaros Sichletidis $^{b}$ \\ Paraskevi Argyropoulou ${ }^{a}$ \\ ${ }^{a}$ Respiratory Failure Unit, ${ }^{b}$ Pulmonary Clinic, and 'Immunology Laboratory, Aristotle University of Thessaloniki, \\ 'G. Papanikolaou Hospital', Thessaloniki, Greece
}

\section{Key Words}

Anemia of chronic disease - Cardiopulmonary exercise testing $\cdot$ Chronic obstructive pulmonary disease $\cdot$ Exercise capacity

\section{Abstract \\ Background: Anemia may be present in patients with chron- ic obstructive pulmonary disease (COPD) and further impair their functional capacity. Objectives: This study investigated the prevalence of anemia of chronic disease (ACD) in COPD patients and its impact on dyspnea and exercise capacity, utilizing cardiopulmonary exercise testing (CPET). Methods: ACD prevalence was assessed in 283 consecutive patients with stable COPD (263 males, 60 females; age $60.31 \pm 5.34$ years; percent forced expiratory volume in $1 \mathrm{~s} 46.94 \pm 6.12$ ). ACD diagnosis was based on a combination of clinical and laboratory parameters [hemoglobin $(\mathrm{Hb})<13 \mathrm{~g} / \mathrm{dl}$ for males, $<12 \mathrm{~g} / \mathrm{dl}$ for females; ferritin $>30 \mathrm{ng} / \mathrm{ml}$; total iron-binding capacity $<250 \mu \mathrm{g} / \mathrm{dl}$, and transferrin saturation rate between 15 and 50\%]. Twenty-seven patients who were identified with ACD (cases) and 27 matched nonanemic patients (con- trols) completed maximal CPET, and data were compared between the groups. Results: ACD was diagnosed in 29 pa-}

tients, which represents a prevalence of $10.24 \%$; the severity of anemia was generally mild (mean Hb: $12.19 \pm 0.66 \mathrm{~g} / \mathrm{dl}$ ). Patients with ACD had a higher Medical Research Council dyspnea score compared to controls ( $2.78 \pm 0.44$ vs. $2.07 \pm$ $0.55 ; \mathrm{p}<0.001)$ and lower peak $\mathrm{O}_{2}$ uptake $\left(\mathrm{VO}_{2}\right)(59.54 \pm 17.17$ vs. $71.26 \pm 11.85 \%$ predicted; $\mathrm{p}<0.05)$, peak work rate (54.94 \pm 21.42 vs. $68.72 \pm 20.81 \%$ predicted; $p<0.05)$ and peak $\mathrm{VO}_{2}$ /heart rate $(69.07 \pm 17.26$ vs. $82.04 \pm 18.22 \%$ predicted; $p<0.05)$. There was also a trend for a lower anaerobic threshold (48.48 \pm 15.16 vs. $55.42 \pm 9.99 \%$ predicted; $p=$ 0.062 ). No exercise parameter indicative of respiratory limitation differed between the groups. Conclusions: ACD occurs in approximately $10 \%$ of stable COPD patients and has a negative impact on dyspnea and circulatory efficiency during exercise.

Copyright $\odot 2011$ S. Karger AG, Basel

\section{Introduction}

Anemia of chronic disease (ACD) is a condition that occurs in patients with acute or chronic immune activation [1-3]. Although the pathogenesis of ACD is not fully understood, there are substantial data supporting the no-

\section{KARGER}

Fax +41613061234

E-Mail karger@karger.ch

www.karger.com
(C) 2011 S. Karger AG, Basel

$0025-7931 / 11 / 0823-0237 \$ 38.00 / 0$

Accessible online at:

www.karger.com/res
Afroditi K. Boutou, MD, MSc

Respiratory Failure Unit

Aristotle University of Thessaloniki, 'G. Papanikolaou Hospital'

GR-57010 Exohi, Thessaloniki (Greece)

Tel. +302313307265, E-Mail afboutou@yahoo.com 
tion that inflammatory cytokines affect iron homeostasis, hemoglobin $(\mathrm{Hb})$ production and the bone marrow response to erythropoietin $[2,4]$. Chronic obstructive pulmonary disease (COPD) is a disorder characterized not only by airflow limitation but also by important systemic manifestations due to the circulation of inflammatory mediators [5-7]. In light of this, COPD is a disorder that could be associated with ACD.

The prevalence of anemia in populations with COPD of various severity ranges from 7.5 to $21.0 \%[8,9]$. However, a combined clinical and laboratory approach has never been used to investigate the specific prevalence of ACD in COPD, while the only study that attempted to associate anemia and inflammation in COPD did not exclude patients with renal impairment [10]. Regardless of its etiology, anemia has been associated with increased morbidity [11] and mortality [9, 11, 12], higher costs of care [9], increased dyspnea [12] and reduced 6-min walk distance [12] in COPD patients. Although cardiopulmonary exercise testing (CPET) can provide a quantitative assessment of a patient's cardiovascular and ventilatory response during exercise [13], both of which can be impaired due to anemia, it has never been used for the functional evaluation of anemic COPD patients.

Based on the aforementioned data, the aims of this study were to (1) estimate the prevalence of ACD based on specific clinical and laboratory criteria in a population of consecutive patients with stable COPD and (2) investigate the impact of ACD on dyspnea and exercise capacity, utilizing CPET.

\section{Material and Methods}

\section{Study Population}

The first part of the study followed a cross-sectional design. The relevant population consisted of consecutive, clinically stable patients with COPD who visited the Respiratory Failure Unit and the Pulmonary Clinic of the 'G. Papanikolaou' Hospital (Thessaloniki, Greece) as outpatients between December 2009 and May 2010. A COPD diagnosis was confirmed, according to the American Thoracic Society criteria, by the presence of a ratio of forced expiratory volume in $1 \mathrm{~s}\left(\mathrm{FEV}_{1}\right)$ to forced vital capacity of $<0.7$ measured after albuterol administration [14]. Patients were characterized as clinically stable if they had had no exacerbation, hospital admission, respiratory infection or change in medication within 3 months prior to entering the study. Subjects with a history of asthma were excluded.

The second part of this project was a case-control study. The first 29 patients with stable COPD and ACD from the initial population were the 'cases' and another 29 COPD patients without ACD, matched for sex, age, height, $\mathrm{FEV}_{1}$ and current smoking status, represented the controls. ACD was defined by the presence of a low $\mathrm{Hb}$ concentration ( $\mathrm{Hb}<13 \mathrm{~g} / \mathrm{dl}$ for males and $<12 \mathrm{~g} / \mathrm{dl}$ for females) among patients in whom any other potential cause of anemia had been excluded based on medical history and laboratory results and was confirmed by the coexistence of a normal or high serum ferritin concentration $(>30 \mathrm{ng} / \mathrm{ml})$, a low transferrin saturation rate ( $>15$ and $<50 \%$ ), low total iron-binding capacity (TIBC; $<250 \mu \mathrm{g} /$ $\mathrm{dl}$ ) and normal folate levels [2, 15-17]. Since low $\mathrm{B}_{12}$ levels occur in about $10-15 \%$ of the elderly but cause anemia only in $1-2 \%$, those patients with low $\mathrm{B}_{12}$ levels were excluded only when they presented macrocytosis [18]. Patients with a history of a malignancy or hematologic disorders, inflammatory bowel disease, acute or chronic infections, systematic or autoimmune disorders, thyroid disease, liver cirrhosis, heart failure (ejection fraction $<55 \%$ ), renal impairment (glomerular filtration rate $<60 \mathrm{ml} / \mathrm{min} / 1.73 \mathrm{~m}^{2}$ ) [19], gastrointestinal or other hemorrhage, blood transfusion within the last 3 months or mental impairment were excluded. Patients with medical conditions which are contraindications to exercise testing according to the American Thoracic Society/American College of Chest Physicians guidelines [20], such as acute myocardial infarction, unstable angina, uncontrolled arrhythmias causing symptoms, orthopedic impairment limiting exercise capacity and room air desaturation $<85 \%$ at rest, were also excluded.

\section{Study Procedures}

During the initial (baseline) visit, all patients with a known or potential COPD diagnosis gave a detailed medical history and underwent physical examination and lung function testing 15 min after albuterol administration. All stable COPD patients underwent peripheral venous blood sampling to determine full blood count, serum levels of urea, creatinine, liver transaminases, total protein (albumin and globulin), vitamin $\mathrm{B}_{12}$, folate, iron, ferritin and TIBC. In approximately $12 \%$ of patients, serum levels of thyroid hormones were also tested due to clinical suspicion of thyroid disease. Transferrin saturation was calculated using the following equation: (serum iron/TIBC) $\times 100$ [15]. Patients who were found to have ACD visited the outpatient clinic within 2 weeks from the baseline visit and performed a physician-supervised maximum CPET on a cycle ergometer; controls underwent the same protocol within a month. The institution's bioethics committee approved the protocol, and all participants gave their informed consent.

Measurements

Spirometry

Complete lung function testing, including measures of lung volume, inspiratory capacity, diffusion capacity and expiratory flow, was performed using standard spirometric techniques (MasterScreen PFT, Jaeger) [21]. All studies were conducted at an altitude of $500 \mathrm{~m}$.

\section{Exercise Testing}

Maximum CPET was performed under continuous monitoring of pulse oximetry, heart rate (HR), arterial pressure and a 12lead electrocardiogram [22]. After 3 min of rest, patients performed $3 \mathrm{~min}$ of unloaded pedaling at $60 \mathrm{rpm}$, followed by a ramp protocol with the work rate (WR) increasing by $10-15 \mathrm{~W} / \mathrm{min}$ until the subject reached his or her symptom-limited maximum [23]. The ramp protocol was personalized for each patient with the aim of reaching maximum exercise in about 10-12 min. All studies were conducted in room air. 


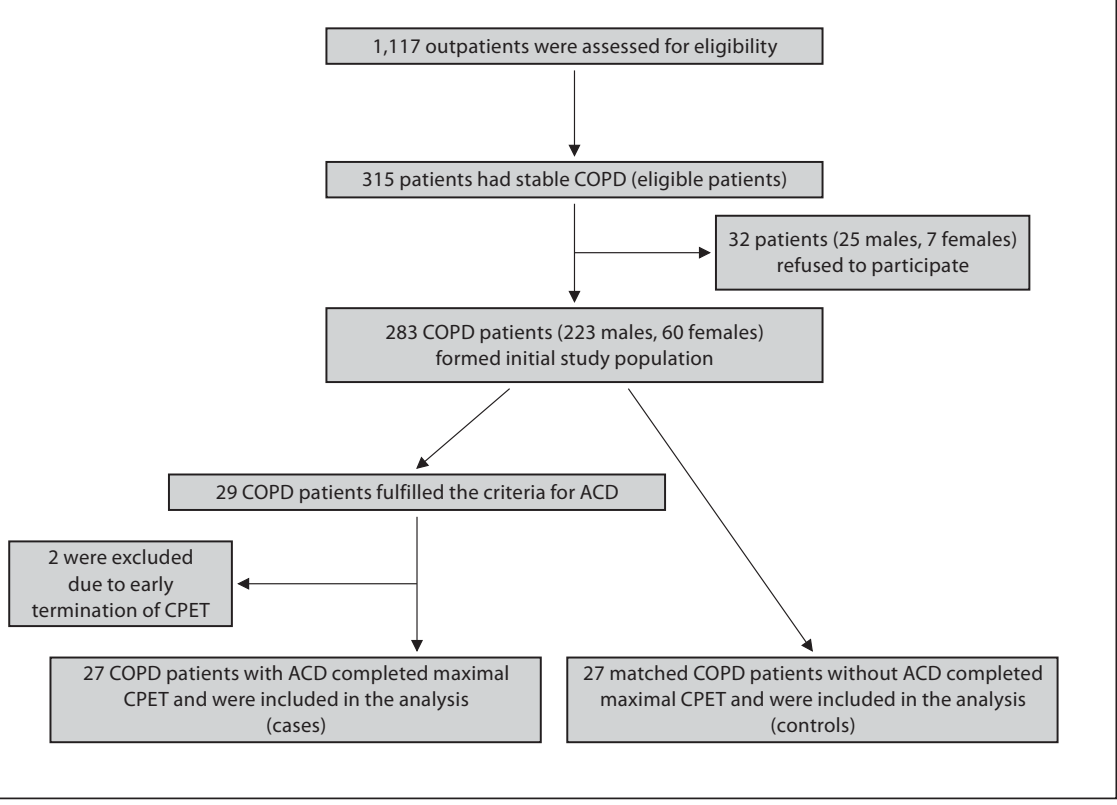

Fig. 1. Study flowchart.

\section{Results}

The study flowchart is presented in figure 1 . From the initial cohort of 1,171 subjects who visited the outpatient clinics, we originally identified 315 COPD patients with stable disease, 283 of whom provided consent and formed the original population (223 males, 60 females; mean age $60.31 \pm 5.34$ years; $\mathrm{FEV}_{1} 46.94 \pm 6.12 \%$ predicted). Twenty-nine patients from this population fulfilled both laboratory and clinical criteria for ACD; therefore, the prevalence of ACD among stable COPD outpatients was $10.24 \%$. The characteristics of the anemic and nonanemic COPD patients are presented in table 1. Patients with ACD were older, had lower $\mathrm{FEV}_{1}$ and presented with more severe disease, according to the Global Initiative for Chronic Obstructive Lung Disease (GOLD) classification [26], compared to the patients without ACD. Moreover, the proportion of males was significantly higher in the group of ACD patients. No difference was noted in weight, body mass index, smoking status, pack-years of smoking, arterial oxygen partial pressure or the proportion of patients who received long-term oxygen treatment between anemic and nonanemic patients. The $\mathrm{Hb}$ level for anemic patients was $12.19 \pm 0.66 \mathrm{~g} / \mathrm{dl}$, and according to anemia severity classification systems $[27,28]$, all patients had mild anemia, i.e. Hb concentration $>10 \mathrm{~g} / \mathrm{dl}$. Anemia was normocytic and normochromic in 27 patients $(25$ males, 2 females), while the remaining 2 (males) had microcytic 
Table 1. Demographic and clinical characteristics of COPD patients with and without ACD

\begin{tabular}{|c|c|c|c|}
\hline & $\begin{array}{l}\text { ACD patients } \\
(\mathrm{n}=29)\end{array}$ & $\begin{array}{l}\text { Non-ACD patients } \\
(\mathrm{n}=254)\end{array}$ & $\mathrm{p}$ \\
\hline \multicolumn{4}{|l|}{ Sex } \\
\hline Male & $27(93.10 \%)$ & $196(77.17 \%)$ & $<0.001$ \\
\hline Female & $2(6.90 \%)$ & $58(22.83 \%)$ & \\
\hline Age, years & $64.63 \pm 8.27$ & $60.29 \pm 5.46$ & 0.031 \\
\hline Height, cm & $167.89 \pm 1.23$ & $166.12 \pm 2.47$ & 0.713 \\
\hline Weight, kg & $71.37 \pm 14.48$ & $73.29 \pm 5.18$ & 0.645 \\
\hline Body mass index, $\mathrm{kg} / \mathrm{m}^{2}$ & $25.01 \pm 3.79$ & $26.53 \pm 4.12$ & 0.296 \\
\hline $\mathrm{Hb}, \mathrm{g} / \mathrm{dl}$ & $12.19 \pm 0.66$ & $14.71 \pm 1.2$ & $<0.001$ \\
\hline \multicolumn{4}{|l|}{$\mathrm{FEV}_{1}$} \\
\hline liters & $1.19 \pm 0.38$ & $1.41 \pm 0.24$ & 0.002 \\
\hline$\%$ predicted & $42.26 \pm 9.76$ & $50.74 \pm 6.12$ & \\
\hline \multicolumn{4}{|c|}{ COPD severity according to GOLD [26] } \\
\hline Moderate (stage II) & $7(24.14 \%)$ & $76(29.92 \%)$ & 0.023 \\
\hline Severe (stage III) & $13(44.83 \%)$ & $119(46.85 \%)$ & \\
\hline Very severe (stage IV) & $9(31.03 \%)$ & $59(23.23 \%)$ & \\
\hline \multicolumn{4}{|l|}{ Smoking status } \\
\hline Never smoked & $2(6.89 \%)$ & $18(7.09 \%)$ & 0.842 \\
\hline Current smokers & $6(20.70 \%)$ & $55(21.65 \%)$ & \\
\hline Ex-smokers & $21(72.41 \%)$ & $181(71.26 \%)$ & \\
\hline Pack-years & $64.21 \pm 29.83$ & $68.70 \pm 33.98$ & 0.912 \\
\hline \multicolumn{4}{|l|}{ LTOT } \\
\hline Yes & $10(34.48 \%)$ & $82(32.28 \%)$ & 0.334 \\
\hline No & $19(65.52 \%)$ & $172(67.72 \%)$ & \\
\hline $\mathrm{PO}_{2}, \mathrm{~mm} \mathrm{Hg}$ & $65.95 \pm 7.90$ & $67.95 \pm 8.13$ & 0.514 \\
\hline
\end{tabular}

Values represent numbers of patients or means \pm SD, as appropriate. LTOT $=$ Long-term oxygen treatment; $\mathrm{PO}_{2}=$ oxygen partial pressure.

and hypochromic anemia. The 2 female patients had a mean $\mathrm{Hb}$ concentration of $11.65 \pm 0.07 \mathrm{~g} / \mathrm{dl}$. Due to the small proportion of females, there was no separate analysis of the patient characteristics by gender.

Two of the 29 COPD patients with ACD were not included in the case-control study because in these patients CPET was prematurely terminated due to a hypertensive crisis (1 male patient) and uncontrolled arrhythmia (1 male patient). Therefore, in the second part of this study, the final population consisted of 27 cases (COPD patients with ACD) and 27 matched controls (COPD patients without ACD), all of whom completed the maximal CPET. The demographic and clinical characteristics and the PFT parameters of the cases and the controls are presented in tables 2 and 3, respectively. The controls were selected to have similar gender, age, height, $\mathrm{FEV}_{1}$ and smoking status to the 27 cases. No difference was found in the remaining PFT parameters, COPD severity according to the GOLD classification [26], pack-years of smoking, the proportion of patients who received long-term oxygen treatment and arterial blood gas analysis parameters between the two groups. However, the controls had significantly higher weight and body mass index compared to the cases.

Exercise capacity parameters for the two groups are presented in table 4 . Five patients ( 3 anemic and 2 nonanemic) completed maximal CPET without reaching the AT. Overall, there was a negative impact of anemia on exercise capacity. Peak $\mathrm{VO}_{2}$, peak WR, WR at the AT, peak $\mathrm{VO}_{2} / \mathrm{HR}$ and $\mathrm{VO}_{2} / \mathrm{HR}$ at the AT were significantly lower among cases compared to controls. There was also a trend for a lower absolute peak $\mathrm{VO}_{2}$ value $(\mathrm{p}=0.072)$ and a lower AT $(\mathrm{p}=0.062)$ in the cases. None of the exercise parameters indicative of respiratory limitation (breathing reserve, peak respiratory rate, maximum $V_{\mathrm{E}}$, maximum $\mathrm{V}_{\mathrm{T}}$, ratio of $\mathrm{V}_{\mathrm{T}}$ at peak exercise to inspiratory capacity and ratio of $\mathrm{V}_{\mathrm{E}}$ at peak exercise to maximum voluntary ventilation) differed between the two groups.

Furthermore, a negative effect of low $\mathrm{Hb}$ levels on breathlessness was noted. Although $\mathrm{Hb}$ concentration was not correlated to the MRC dyspnea score, the cases 
Table 2. Demographic and clinical characteristics of cases and controls

\begin{tabular}{|c|c|c|c|}
\hline & $\begin{array}{l}\text { Cases } \\
(n=27)\end{array}$ & $\begin{array}{l}\text { Controls } \\
(\mathrm{n}=27)\end{array}$ & $\mathrm{p}$ \\
\hline \multicolumn{4}{|l|}{ Sex } \\
\hline Male & $25(92.59 \%)$ & $25(92.59 \%)$ & 1.0 \\
\hline Female & $2(7.41 \%)$ & $2(7.41 \%)$ & \\
\hline Age, years & $64.82 \pm 8.01$ & $65.33 \pm 7.24$ & 0.741 \\
\hline Height, cm & $167.21 \pm 2.13$ & $168.89 \pm 5.57$ & 0.537 \\
\hline Weight, kg & $72.16 \pm 14.02$ & $83.33 \pm 14.18$ & 0.003 \\
\hline Body mass index, $\mathrm{kg} / \mathrm{m}^{2}$ & $25.32 \pm 4.72$ & $29.19 \pm 4.18$ & 0.003 \\
\hline $\mathrm{Hb}, \mathrm{g} / \mathrm{dl}$ & $12.15 \pm 0.72$ & $14.57 \pm 0.75$ & $<0.001$ \\
\hline $\mathrm{MCV}, \mathrm{fl}$ & $87.01 \pm 8.06$ & $89.98 \pm 4.13$ & 0.071 \\
\hline $\mathrm{MCH}, \mathrm{pg} / \mathrm{cell}$ & $28.04 \pm 2.98$ & $29.77 \pm 1.63$ & 0.101 \\
\hline $\mathrm{MCHC}, \mathrm{g} / \mathrm{dl}$ & $32.18 \pm 1.66$ & $32.99 \pm 0.84$ & 0.099 \\
\hline \multicolumn{4}{|c|}{ COPD severity according to GOLD [26] } \\
\hline Moderate (stage II) & $6(22.22 \%)$ & $7(25.92 \%)$ & 0.632 \\
\hline Severe (stage III) & $12(44.45 \%)$ & $11(40.75 \%)$ & \\
\hline Very severe (stage IV) & $9(33.33 \%)$ & $9(33.33 \%)$ & \\
\hline \multicolumn{4}{|l|}{ Smoking status } \\
\hline Never smoked & $2(7.41 \%)$ & $2(7.41 \%)$ & 0.711 \\
\hline Current smokers & $6(22.22 \%)$ & $5(18.52 \%)$ & \\
\hline Ex-smokers & $19(70.37 \%)$ & $20(74.07 \%)$ & \\
\hline Pack-years & $62.98 \pm 27.33$ & $65.34 \pm 25.41$ & 0.695 \\
\hline \multicolumn{4}{|l|}{ LTOT } \\
\hline Yes & $8(29.63 \%)$ & $6(22.22 \%)$ & 0.101 \\
\hline No & $19(70.37 \%)$ & $21(77.78 \%)$ & \\
\hline $\mathrm{PO}_{2}, \mathrm{~mm} \mathrm{Hg}$ & $66.82 \pm 7.20$ & $68.76 \pm 6.95$ & 0.252 \\
\hline $\mathrm{PCO}_{2}, \mathrm{~mm} \mathrm{Hg}$ & $40.12 \pm 5.01$ & $41.95 \pm 3.97$ & 0.107 \\
\hline $\mathrm{pH}$ & $7.41 \pm 0.03$ & $7.41 \pm 0.02$ & 0.500 \\
\hline
\end{tabular}

Values represent numbers of patients or means $\pm \mathrm{SD}$, as appropriate. MCV $=$ Mean corpuscular (erythrocyte) volume; $\mathrm{MCH}=$ mean corpuscular $\mathrm{Hb} ; \mathrm{MCHC}=$ mean corpuscular $\mathrm{Hb}$ concentration; $\mathrm{LTOT}=$ long-term oxygen treatment; $\mathrm{PO}_{2}=$ oxygen partial pressure; $\mathrm{PCO}_{2}=$ carbon dioxide partial pressure.

had a significantly higher dyspnea scale score than the controls ( $2.78 \pm 0.44$ vs. $2.07 \pm 0.55 ; \mathrm{p}<0.001)$.

Investigating for potential associations between $\mathrm{Hb}$ levels and CPET parameters, we noted intermediate correlations between $\mathrm{Hb}$ concentration and $\mathrm{WR}$ at the AT $(\mathrm{r}=0.432, \mathrm{p}=0.002)$, peak $\mathrm{VO}_{2} / \mathrm{HR}(\mathrm{r}=0.412, \mathrm{p}=0.003)$, $\mathrm{VO}_{2} / \mathrm{HR}$ at the AT $(\mathrm{r}=0.431, \mathrm{p}=0.004)$ and peak $\mathrm{VO}_{2}$ $(\mathrm{r}=0.436, \mathrm{p}=0.001)$. In contrast, no correlation was evident between $\mathrm{Hb}$ values and any of the exercise parameters which reflect respiratory limitation.

\section{Discussion}

The present study is the first to examine the prevalence of ACD in a population of stable COPD patients using a combination of clinical and laboratory criteria. Ap- proximately 1 out of 10 stable COPD patients had ACD. This study is also the first to investigate the impact of ACD on exercise capacity, utilizing CPET. Exercise capacity was significantly lower and the MRC dyspnea score was significantly higher in ACD patients compared to controls.

At the time of this writing, a few studies had evaluated the prevalence of anemia among COPD outpatients, but their results vary significantly. The highest frequency of anemia was noted in a study by Halpern et al. [9], where $21 \%$ of elderly COPD outpatients presented with low $\mathrm{Hb}$ levels ( $<13 \mathrm{~g} / \mathrm{dl}$ for males and $<12 \mathrm{~g} / \mathrm{dl}$ for females); however, all patients were over 65 years of age, and significant causes of anemia, such as infectious diseases and connective tissue disorders, were not excluded. Cote et al. [12] estimated the prevalence of anemia among stable COPD patients to be $17 \%$, but this percentage referred to anemia 
Table 3. PFT parameters among cases and controls

\begin{tabular}{|c|c|c|c|}
\hline & $\begin{array}{l}\text { Cases } \\
(n=27)\end{array}$ & $\begin{array}{l}\text { Controls } \\
(\mathrm{n}=27)\end{array}$ & $\mathrm{p}$ \\
\hline \multicolumn{4}{|l|}{$\mathrm{FEV}_{1}$} \\
\hline liters & $1.18 \pm 0.32$ & $1.21 \pm 0.41$ & 0.881 \\
\hline$\%$ predicted & $42.30 \pm 9.98$ & $42.76 \pm 12.83$ & 0.827 \\
\hline \multicolumn{4}{|l|}{ FVC } \\
\hline liters & $2.34 \pm 0.74$ & $2.73 \pm 0.97$ & 0.108 \\
\hline$\%$ predicted & $67.88 \pm 18.08$ & $71.63 \pm 19.61$ & 0.137 \\
\hline $\mathrm{FEV}_{1} / \mathrm{FVC}$ & $48.94 \pm 6.04$ & $47.93 \pm 13.53$ & 0.726 \\
\hline \multicolumn{4}{|l|}{$\mathrm{FEF}_{25}$} \\
\hline liters & $1.31 \pm 0.51$ & $1.58 \pm 1.07$ & 0.252 \\
\hline$\%$ predicted & $19.31 \pm 7.63$ & $21.19 \pm 12.98$ & 0.326 \\
\hline \multicolumn{4}{|l|}{$\mathrm{FEF}_{50}$} \\
\hline liters & $0.58 \pm 0.28$ & $0.56 \pm 0.23$ & 0.729 \\
\hline$\%$ predicted & $14.62 \pm 6.96$ & $13.20 \pm 5.07$ & 0.400 \\
\hline \multicolumn{4}{|l|}{$\mathrm{FEF}_{75}$} \\
\hline liters & $0.22 \pm 0.09$ & $0.23 \pm 0.12$ & 0.832 \\
\hline$\%$ predicted & $16.49 \pm 7.34$ & $15.37 \pm 8.43$ & 0.606 \\
\hline \multicolumn{4}{|l|}{ PEF } \\
\hline liters & $3.27 \pm 1.26$ & $3.04 \pm 1.87$ & 0.605 \\
\hline$\%$ predicted & $42.74 \pm 14.89$ & $40.39 \pm 21.32$ & 0.641 \\
\hline \multicolumn{4}{|l|}{ TLC } \\
\hline liters & $6.05 \pm 1.54$ & $6.63 \pm 1.12$ & 0.261 \\
\hline$\%$ predicted & $96.09 \pm 23.97$ & $102.45 \pm 13.53$ & 0.258 \\
\hline \multicolumn{4}{|l|}{ FRC } \\
\hline liters & $4.22 \pm 1.23$ & $4.19 \pm 0.98$ & 0.665 \\
\hline$\%$ predicted & $122.79 \pm 35.64$ & $119.98 \pm 27.28$ & 0.597 \\
\hline \multicolumn{4}{|l|}{ VC } \\
\hline liters & $2.60 \pm 0.80$ & $2.96 \pm 0.97$ & 0.159 \\
\hline$\%$ predicted & $71.02 \pm 19.99$ & $76.47 \pm 19.56$ & 0.245 \\
\hline \multicolumn{4}{|l|}{ IC } \\
\hline liters & $2.20 \pm 0.59$ & $2.15 \pm 0.81$ & 0.131 \\
\hline$\%$ predicted & $75.13 \pm 23.75$ & $73.51 \pm 22.42$ & 0.101 \\
\hline \multicolumn{4}{|l|}{ RV } \\
\hline liters & $3.35 \pm 1.11$ & $3.62 \pm 0.75$ & 0.332 \\
\hline$\%$ predicted & $143.22 \pm 47.50$ & $149.72 \pm 32.40$ & 0.583 \\
\hline \multicolumn{4}{|l|}{$\mathrm{T}_{\mathrm{LCO}}$} \\
\hline $\mathrm{mmol} \cdot \mathrm{min}^{-1} \cdot \mathrm{kPa}^{-1}$ & $2.10 \pm 0.67$ & $2.41 \pm 1.04$ & 0.222 \\
\hline$\%$ predicted & $63.78 \pm 21.69$ & $70.54 \pm 15.29$ & 0.131 \\
\hline \multicolumn{4}{|l|}{$\mathrm{T}_{\mathrm{LCOC}}$} \\
\hline $\mathrm{mmol} \cdot \mathrm{min}^{-1} \cdot \mathrm{kPa}^{-1}$ & $2.77 \pm 1.13$ & $2.28 \pm 0.63$ & 0.337 \\
\hline$\%$ predicted & $72.18 \pm 15.22$ & $64.69 \pm 13.24$ & 0.192 \\
\hline \multicolumn{4}{|l|}{$\mathrm{K}_{\mathrm{CO}}$} \\
\hline $\mathrm{mmol} \cdot \mathrm{min}^{-1} \cdot \mathrm{kPa}^{-1} \cdot 1^{-1}$ & $0.52 \pm 0.33$ & $0.56 \pm 0.27$ & 0.214 \\
\hline$\%$ predicted & $57.14 \pm 34.79$ & $58.57 \pm 17.49$ & 0.881 \\
\hline \multicolumn{4}{|l|}{$\mathrm{K}_{\mathrm{CO}} \mathrm{C}$} \\
\hline $\mathrm{mmol} \cdot \mathrm{min}^{-1} \cdot \mathrm{kPa}^{-1} \cdot \mathrm{l}^{-1}$ & $0.60 \pm 0.26$ & $0.52 \pm 0.23$ & 0.331 \\
\hline$\%$ predicted & $61.54 \pm 19.16$ & $55.07 \pm 22.04$ & 0.231 \\
\hline $\mathrm{V}_{\mathrm{A}}$, liters & $4.28 \pm 1.28$ & $4.38 \pm 0.85$ & 0.634 \\
\hline
\end{tabular}

$\mathrm{FVC}=$ Forced vital capacity; FEF = forced expiratory flow; $\mathrm{PEF}=$ peak expiratory flow; TLC $=$ total lung capacity; FRC = functional residual capacity; $\mathrm{VC}=$ vital capacity; $\mathrm{IC}=$ inspiratory capacity; $\mathrm{RV}=$ residual volume; $\mathrm{T}_{\mathrm{LCO}}=$ carbon monoxide transfer factor; $\mathrm{T}_{\mathrm{LCO}} \mathrm{C}=$ carbon monoxide transfer factor corrected for $\mathrm{Hb}$ concentration; $\mathrm{K}_{\mathrm{CO}}=$ carbon monoxide transfer coefficient; $\mathrm{K}_{\mathrm{CO}} \mathrm{C}=$ carbon monoxide transfer coefficient corrected for $\mathrm{Hb}$ concentration; $\mathrm{V}_{\mathrm{A}}=$ alveolar ventilation. of all causes. In the only previous study that attempted to make a pathophysiologic connection between COPD, anemia and inflammation [10], the prevalence of anemia was $13 \%$; however, apart from $\mathrm{Hb}$ concentration, no other laboratory parameter was used to diagnose ACD, and the renal function of the patients was not determined. The present study is the only one which uses a combination of clinical and laboratory parameters to indicate that ACD occurs frequently in COPD and could be present in approximately $10 \%$ of stable COPD patients.

Anemia has been repeatedly associated with reduced exercise capacity in patients with chronic kidney disease $[29,30]$, chronic heart failure $[31,32]$ and cancer $[33,34]$. Although the underlying pathophysiologic mechanisms are complex, the role of compromised oxygen delivery to the mitochondria seems crucial. The oxygen-carrying capacity of the blood depends directly on the level of $\mathrm{Hb}$ [12], and in normal individuals, $15 \mathrm{~g} / \mathrm{dl}$ of $\mathrm{Hb}$ carry approximately $21 \mathrm{ml}$ of oxygen per $100 \mathrm{ml}$ of blood [35]. In these subjects, a $3 \mathrm{~g} / \mathrm{dl}$ decrease in $\mathrm{Hb}$ levels would result in a reduction of the total oxygen-carrying capacity by $4 / 100 \mathrm{ml}$; this effect may be more intense in patients with respiratory disorders, since the saturation of $\mathrm{Hb}$ is usually abnormal. Peak oxygen uptake equals cardiac output $\times$ arteriovenous $\mathrm{O}_{2}$ difference [31], so it has been suggested that for a given increase in cardiac output, the anemic patient, who has a decreased arterial $\mathrm{O}_{2}$ concentration, will have a lower peak $\mathrm{VO}_{2}$. Furthermore, when the arterial oxygen content is low, the diffusion gradient of oxygen from the blood to the mitochondria decreases more rapidly, leading to early anaerobic metabolism [23].

The present study confirms the above hypotheses. Anemic patients had lower peak $\mathrm{VO}_{2}$ and lower $\mathrm{VO}_{2} / \mathrm{HR}$ (both at the AT and at peak exercise) and achieved lower WR compared to the nonanemic controls, while there was also a trend for a lower AT. In the only previous study that evaluated the impact of anemia on exercise capacity, low $\mathrm{Hb}$ levels were a predictor of reduced 6-min walk distance among COPD patients [12]; the present study confirms these results and demonstrates the negative effect of ACD on numerous exercise parameters.

Breathlessness is a common symptom among patients with anemia. In the study of Cote et al. [12], anemic COPD patients had a significantly higher MRC dyspnea score and anemia was an independent predictor of increased dyspnea. The present study showed that the severity of dyspnea differed significantly between COPD patients with and without ACD. It has been suggested that the early onset of the AT, resulting in lactate production and metabolic acidosis, could be a cause of high ven- 
Table 4. CPET parameters in cases and controls, separately and combined

\begin{tabular}{|c|c|c|c|c|}
\hline & $\begin{array}{l}\text { Total population } \\
(\mathrm{n}=54)\end{array}$ & $\begin{array}{l}\text { Cases } \\
(n=27)\end{array}$ & $\begin{array}{l}\text { Controls } \\
(\mathrm{n}=27)\end{array}$ & $\mathrm{p}$ \\
\hline Peak $\mathrm{VO}_{2}, \mathrm{ml} / \mathrm{kg} \cdot \min$ & $16.77 \pm 4.10$ & $16.03 \pm 3.87$ & $17.82 \pm 3.98$ & 0.078 \\
\hline Peak $\mathrm{VO}_{2}, \%$ predicted & $65.40 \pm 15.76$ & $59.54 \pm 17.17$ & $71.26 \pm 11.85$ & 0.005 \\
\hline $\mathrm{AT}, \mathrm{ml} / \mathrm{kg} \cdot \mathrm{min}$ & $13.30 \pm 3.20$ & $12.94 \pm 2.72$ & $13.61 \pm 3.58$ & NS \\
\hline AT, $\%$ predicted & $52.16 \pm 13.02$ & $48.48 \pm 15.16$ & $55.42 \pm 9.99$ & 0.062 \\
\hline Peak WR, W & $76.75 \pm 28.68$ & $67.04 \pm 24.86$ & $86.11 \pm 29.42$ & 0.014 \\
\hline Peak WR, \% predicted & $62.10 \pm 22.02$ & $54.94 \pm 21.42$ & $68.72 \pm 20.81$ & 0.023 \\
\hline $\mathrm{WR}$ at $\mathrm{AT}, \mathrm{W}$ & $58.06 \pm 22.40$ & $49.81 \pm 18.12$ & $64.73 \pm 23.62$ & 0.021 \\
\hline Peak $\mathrm{VO}_{2} / \mathrm{HR}, \mathrm{ml} /$ beat & $9.60 \pm 2.60$ & $8.81 \pm 1.98$ & $10.42 \pm 2.94$ & 0.023 \\
\hline Peak $\mathrm{VO}_{2} / \mathrm{HR}, \%$ predicted & $75.43 \pm 18.74$ & $69.07 \pm 17.26$ & $82.04 \pm 18.22$ & 0.010 \\
\hline $\mathrm{VO}_{2} / \mathrm{HR}$ at $\mathrm{AT}, \mathrm{ml} /$ beat & $8.74 \pm 2.33$ & $7.95 \pm 1.65$ & $9.39 \pm 2.62$ & 0.044 \\
\hline Peak HR, \% predicted & $85.50 \pm 10.69$ & $85.14 \pm 10.42$ & $85.87 \pm 11.14$ & NS \\
\hline $\mathrm{PETCO}_{2}$ at $\mathrm{AT}$ & $36.64 \pm 5.49$ & $35.41 \pm 6.27$ & $37.72 \pm 4.56$ & NS \\
\hline $\mathrm{VE} / \mathrm{VCO}_{2}$ at $\mathrm{AT}$ & $35.23 \pm 6.70$ & $36.82 \pm 7.74$ & $33.84 \pm 5.36$ & NS \\
\hline $\mathrm{V}_{\mathrm{E}} \max$, liters & $43.19 \pm 13.61$ & $41.34 \pm 13.33$ & $44.94 \pm 13.74$ & NS \\
\hline $\mathrm{V}_{\mathrm{T}} \max$, liters & $1.28 \pm 0.36$ & $1.24 \pm 0.06$ & $1.31 \pm 0.07$ & NS \\
\hline $\mathrm{V}_{\mathrm{T}} \max / \mathrm{IC}$ & $0.78 \pm 0.62$ & $0.82 \pm 0.26$ & $0.74 \pm 0.85$ & NS \\
\hline $\mathrm{V}_{\mathrm{E}} \max / \mathrm{MVV}$ & $0.91 \pm 0.15$ & $0.89 \pm 0.12$ & $0.92 \pm 0.03$ & NS \\
\hline $\mathrm{BR}$, liters & $4.49 \pm 6.84$ & $5.37 \pm 0.95$ & $3.64 \pm 1.60$ & NS \\
\hline Peak RR, breaths/min & $35.53 \pm 6.67$ & $35.74 \pm 1.45$ & $35.31 \pm 1.13$ & NS \\
\hline Resting $\mathrm{SaO}_{2}, \%$ & $95.06 \pm 2.42$ & $94.88 \pm 2.57$ & $95.30 \pm 2.06$ & NS \\
\hline Peak $\mathrm{SaO}_{2}, \%$ & $91.29 \pm 5.62$ & $90.88 \pm 5.95$ & $91.74 \pm 5.34$ & NS \\
\hline
\end{tabular}

$\mathrm{PETCO}_{2}=$ End-tidal carbon dioxide; $\mathrm{VE} / \mathrm{VCO}_{2}=$ ventilatory equivalent for carbon dioxide; $\mathrm{IC}=$ inspiratory capacity; MVV = maximum voluntary ventilation; $\mathrm{BR}=$ breathing reserve; $\mathrm{RR}=$ respiratory rate; $\mathrm{SaO}_{2}=$ oxygen saturation; NS = not significant.

tilatory drive and increased dyspnea $[12,23]$ due to the stimulation of peripheral chemoreceptors [36]. This hypothesis needs to be investigated further.

While the presence of anemia is associated with adverse outcomes, its correction has proven beneficial in several chronic disease states. Correction of anemia has been associated with improved renal function, exercise tolerance and New York Heart Association class in heart failure patients and with better quality of life, exercise capacity and cognitive function in chronic renal failure patients [37-40]. The correction of anemia with blood transfusion in COPD patients resulted in the reduction of $\mathrm{V}_{\mathrm{E}}$ and work of breathing [41], while in another study, 5 COPD patients were successfully weaned from mechanical ventilation after their anemia was treated [42]. Although investigating the impact of anemia correction was not the aim of this study, the results imply that hematocrit normalization may be beneficial for COPD patients. However, the therapeutic approach to ACD remains controversial [2], and prospective, large-scale clinical trials are necessary in order to identify which patients will benefit from the use of blood transfusions, iron supplementation, erythropoietin or anti-inflammatory agents.

In the current study, special attention was paid to matching COPD cases and controls with regard to most of the known parameters that could affect their exercise performance. In a previous, cross-sectional study, the anemic COPD patients were older and had a higher disease burden than the nonanemic ones, and these characteristics had probably affected their functional capacity [8]. By controlling for these confounders, the impact of low $\mathrm{Hb}$ on exercise capacity became more evident in our study. However, there are also limitations to our study. The proportion of female patients was small, as also seen in previous studies of anemia among COPD patients [10, 12]. The significantly lower prevalence of COPD in females in Greece $[43,44]$ and the lower frequency of anemia in women $>65$ years old compared to men of the same age [45] are possible explanations for this phenomenon. However, previous studies that investigated the impact of anemia on elderly females in non-COPD settings 
had similar results, so the possibility that the results may not be generalized to both genders is remote $[46,47]$. Further, this COPD population which was followed up at a major urban hospital had more severe disease than patients in a primary care setting [48], so ACD might not be as frequent in the general COPD population.

In conclusion, this is the first study to establish that COPD can be accompanied by ACD, by utilizing a combination of clinical and laboratory parameters. The careful case-control comparison has shown that there is a negative impact of ACD on both exercise capacity and the severity of the dyspnea score. Future studies are needed in order to investigate the potential role of inflammatory mediators on the suppression of erythropoiesis in patients with COPD and to evaluate the possible therapeutic approaches in this population.

\section{Financial Disclosure and Conflicts of Interest}

None to declare for any of the authors.

\section{References}

1 Weiss G: Pathogenesis and treatment of anaemia of chronic disease. Blood Rev 2002; 16:87-96.

2 Weiss G, Goodnough LT: Anemia of chronic disease. N Engl J Med 2005;352:1011-1023.

- 3 Means RT Jr, Krantz SB: Progress in understanding the pathogenesis of the anemia of chronic disease. Blood 1992;80:1639-1647.

4 Nemeth E, Rivera S, Gabayan V, Keller C, Taudorf S, Pedersen BK, Ganz T: IL-6 mediates hypoferremia of inflammation by inducing the synthesis of the iron regulatory hormone hepcidin. J Clin Invest 2004;113: 1271-1276.

5 Barnes PJ, Celli BR: Systemic manifestations and comorbidities of COPD. Eur Respir J 2009;33:1165-1185.

6 van Helvoort HA, Heijdra YF, Dekhuijzen $\mathrm{PN}$ : Systemic immunological response to exercise in patients with chronic obstructive pulmonary disease: what does it mean? Respiration 2006;73:255-264.

7 Landbo C, Prescott E, Lange P, Vestbo J, Almdal TP: Prognostic value of nutritional status in chronic obstructive pulmonary disease. Am J Respir Crit Care Med 1999;160: 1856-1861.

8 Krishnan G, Grant BJ, Muti PC, Mishra A, Ochs-Balcom HM, Freudenheim JL, Trevisan $\mathrm{M}$, Schünemann $\mathrm{HJ}$ : Association between anemia and quality of life in a population sample of individuals with chronic obstructive pulmonary disease. BMC Pulm Med 2006;6:23.

9 Halpern MT, Zilberberg MD, Schmier JK, Lau EC, Shorr AF: Anemia, costs and mortality in chronic obstructive pulmonary disease. Cost Eff Resour Alloc 2006;4:17.

10 John M, Hoernig S, Doehner W, Okonko DD, Witt C, Anker SD: Anemia and inflammation in COPD. Chest 2005;127:825-829.

- 11 Chambellan A, Chailleux E, Similowski T: Prognostic value of the hematocrit in patients with severe COPD receiving long-term oxygen therapy. Chest 2005;128:1201-1208.
Cote C, Zilberberg MD, Mody SH, Dordelly LJ, Celli B: Haemoglobin level and its clinical impact in a cohort of patients with COPD. Eur Respir J 2007;29:923-929.

13 Ferrazza AM, Martolini D, Valli G, Palange P: Cardiopulmonary exercise testing in the functional and prognostic evaluation of patients with pulmonary diseases. Respiration 2009;77:3-17.

14 Celli BR, MacNee W: Standards for the diagnosis and treatment of patients with COPD: a summary of the ATS/ERS position paper. Eur Respir J 2004;23:932-946.

-15 Tettamanti M, Lucca U, Gandini F, Recchia A, Mosconi P, Apolone G, Nobili A, Tallone MV, Detoma P, Giacomin A, Clerico M, Tempia P, Savoia L, Fasolo G, Ponchio L, Della Porta MG, Riva E: Prevalence, incidence and types of mild anemia in the elderly: the 'Health and Anemia' population-based study. Haematologica 2010;95:1849-1856.

16 Ahluwalia N, Lammi-Keefe CJ, Bendel RB, Morse EE, Beard JL, Haley NR: Iron deficiency and anemia of chronic disease in elderly women: a discriminant-analysis approach for differentiation. Am J Clin Nutr 1995;61:590-596.

17 Looker AC, Dallman PR, Carroll MD, Gunter EW, Johnson CL: Prevalence of iron deficiency in the United States. JAMA 1997;277: 973-976.

18 Carmel R, Green R, Rosenblatt DS, Watkins D: Update on cobalamin, folate, and homocysteine. Hematology Am Soc Hematol Educ Program 2003:62-81.

19 Rossert J, Froissart M: Role of anemia in progression of chronic kidney disease. Semin Nephrol 2006;26:283-289.

20 ATS/ACCP: Statement on cardiopulmonary exercise testing. Am J Respir Crit Care Med 2003;167:211-277.
1 Miller MR, Hankinson J, Brusasco V, Burgos F, Casaburi R, Coates A, Crapo R, Enright P, van der Grinten CP, Gustafsson P, Jensen R, Johnson DC, MacIntyre N, McKay R, Navajas D, Pedersen OF, Pellegrino R, Viegi G, Wanger J; ATS/ERS Task Force: Standardisation of spirometry. Eur Respir J 2005;26:319338.

22 Ross RM: ATS/ACCP statement on cardiopulmonary exercise testing. Am J Respir Crit Care Med 2003;167:1451.

23 Wasserman K, Hansen LE, Sue DY, Stringer WW, Whipp BJ: Principles of Exercise Testing and Interpretation, ed 4. Philadelphia, Lippincott Williams \& Wilkins, 2005.

24 Beaver WL, Wasserman K, Whipp BJ: A new method for detecting anaerobic threshold by gas exchange. J Appl Physiol 1986;60:20202027.

-25 Knudson RJ, Lebowitz MD, Holberg CJ, Burrows $\mathrm{B}$ : Changes in the normal maximal expiratory flow-volume curve with growth and aging. Am Rev Respir Dis 1983;127:725-734.

26 Gold PM: The 2007 GOLD Guidelines: a comprehensive care framework. Respir Care 2009;54:1040-1049.

27 Groopman JE, Itri LM: Chemotherapy-induced anemia in adults: incidence and treatment. J Natl Cancer Inst 1999;91:1616-1634.

28 Wilson A, Yu HT, Goodnough LT, Nissenson AR: Prevalence and outcomes of anemia in rheumatoid arthritis: a systematic review of the literature. Am J Med 2004;116(suppl 7A):50S-57S

29 Eknoyan G: The importance of early treatment of the anaemia of chronic kidney disease. Nephrol Dial Transplant 2001;16(suppl 5):45-49.

30 Odden MC, Whooley MA, Shlipak MG: Association of chronic kidney disease and anemia with physical capacity: the heart and soul study. J Am Soc Nephrol 2004;15:29082915 . 
-31 Agostoni P, Salvioni E, Debenedetti C, Vignati C, Cattadori G, Contini M, Magrì D, Palermo P, Gondoni E, Brusoni D, Fiorentini C, Apostolo A: Relationship of resting hemoglobin concentration to peak oxygen uptake in heart failure patients. Am J Hematol 2010; 85:414-417.

32 Mancini DM, Katz SD, Lang CC, LaManca J, Hudaihed A, Androne AS: Effect of erythropoietin on exercise capacity in patients with moderate to severe chronic heart failure. Circulation 2003;107:294-299.

33 Evans WJ: Physical function in men and women with cancer. Effects of anemia and conditioning. Oncology (Williston Park) 2002;16(9 suppl 10):109-115.

>34 Dudgeon DJ, Lertzman M, Askew GR: Physiological changes and clinical correlations of dyspnea in cancer outpatients. J Pain Symptom Manage 2001;21:373-379.

35 Culver BH: Physiology; in Albert RK, Spiro SG, Jett JR (eds): Comprehensive Respiratory Medicine, ed 1. St Louis, Mosby Inc, 1999, pp 89-150.

36 O’Regan RG, Majcherczyk S: Role of peripheral chemoreceptors and central chemosensitivity in the regulation of respiration and circulation. J Exp Biol 1982;100:23-40.

-37 Palazzuoli A, Quatrini I, Calabrò A, Antonelli G, Caputo M, Campagna MS, Franci B, Nuti R: Anemia correction by erythropoietin reduces $\mathrm{BNP}$ levels, hospitalization rate, and NYHA class in patients with cardio-renal anemia syndrome. Clin Exp Med 2011; 11:43-48.
38 Palazzuoli A, Silverberg D, Iovine F, Capobianco S, Giannotti G, Calabrò A, Campagna MS, Nuti R: Erythropoietin improves anemia exercise tolerance and renal function and reduces B-type natriuretic peptide and hospitalization in patients with heart failure and anemia. Am Heart J 2006;152:1096.e91096.e15.

39 Silverberg DS, Wexler D, Blum M, Sheps D, Schwartz D, Yachnin T, Baruch R, Tchebiner J, Zubkov A, Shaked M, Steinbruch S, Keren G, Iaina A: Aggressive therapy of congestive heart failure and associated chronic renal failure with medications and correction of anemia stops or slows the progression of both diseases. Perit Dial Int 2001;21(suppl 3):S236-S240.

40 Bedani PL, Verzola A, Bergami M, Stabellini G, Gilli P: Erythropoietin and cardiocirculatory condition in aged patients with chronic renal failure. Nephron 2001;89:350-353.

41 Schonhofer B, Wenzel M, Geibel M, Kohler D: Blood transfusion and lung function in chronically anemic patients with severe chronic obstructive pulmonary disease. Crit Care Med 1998;26:1824-1828.

42 Schonhofer B, Bohrer H, Kohler D: Blood transfusion facilitating difficult weaning from the ventilator. Anaesthesia 1998;53: 181-184.
43 Sichletidis L, Tsiotsios I, Gavriilidis A Chloros D, Kottakis I, Daskalopoulou E, Konstantinidis T: Prevalence of chronic obstructive pulmonary disease and rhinitis in northern Greece. Respiration 2005;72:270277.

44 Tzanakis N, Anagnostopoulou U, Filaditaki V, Christaki P, Siafakas N: Prevalence of COPD in Greece. Chest 2004;125:892-900.

45 Guralnik JM, Eisenstaedt RS, Ferrucci L, Klein HG, Woodman RC: Prevalence of anemia in persons 65 years and older in the United States: evidence for a high rate of unexplained anemia. Blood 2004;104:2263-2268.

46 Chaves PH, Ashar B, Guralnik JM, Fried LP: Looking at the relationship between hemoglobin concentration and prevalent mobility difficulty in older women. Should the criteria currently used to define anemia in older people be reevaluated? J Am Geriatr Soc 2002;50:1257-1264

47 Chaves PH, Semba RD, Leng SX, Woodman RC, Ferrucci L, Guralnik JM, Fried LP: Impact of anemia and cardiovascular disease on frailty status of community-dwelling older women: the Women's Health and Aging Studies I and II. J Gerontol A Biol Sci Med Sci 2005;60:729-735.

48 Minas M, Hatzoglou C, Karetsi E, Tanou K, Tsaroucha R, Gogou E, Gourgoulianis KI, Kostikas K: COPD prevalence and the differences between newly and previously diagnosed COPD patients in a spirometry program. Prim Care Respir J 2010;19:363-370. 


\section{Erratum}

The authors of the article 'Anemia of Chronic Disease in Chronic Obstructive Pulmonary Disease: A Case-Control Study of Cardiopulmonary Exercise Responses', published in Respiration 2011;82:237-245, wish to correct the following error on page 238, in the Material and Methods section, first paragraph of Study Population, in the 5th line: the phrase 'December 2009' should be replaced by 'June 2009'.

The correct sentence should read as follows:

'The relevant population consisted of consecutive, clinically stable patients with COPD who visited the Respiratory Failure Unit and the Pulmonary Clinic of the 'G. Papanikolaou' Hospital (Thessaloniki, Greece) as outpatients between June 2009 and May 2010.' 